\title{
Quercus rotundifolia Bark as a Source of Polar Extracts: Structural and Chemical Characterization
}

\author{
Vicelina Sousa *, Joana P. A. Ferreira, Isabel Miranda, Teresa Quilhó (D) and Helena Pereira (D) \\ Centro de Estudos Florestais, Instituto Superior de Agronomia, Universidade de Lisboa, Tapada da Ajuda, \\ 1349-017 Lisboa, Portugal; jpferreira@isa.ulisboa.pt (J.P.A.F.); imiranda@isa.ulisboa.pt (I.M.); \\ terisantos@isa.ulisboa.pt (T.Q.); hpereira@isa.ulisboa.pt (H.P.) \\ * Correspondence: vsousa@isa.ulisboa.pt
}

Citation: Sousa, V.; Ferreira, J.P.A.; Miranda, I.; Quilhó, T.; Pereira, H. Quercus rotundifolia Bark as a Source of Polar Extracts: Structural and Chemical Characterization. Forests 2021, 12, 1160. https://doi.org/ 10.3390/f12091160

Academic Editor: Apostolos

P. Kyriazopoulos

Received: 28 July 2021

Accepted: 23 August 2021

Published: 27 August 2021

Publisher's Note: MDPI stays neutral with regard to jurisdictional claims in published maps and institutional affiliations.

Copyright: (c) 2021 by the authors. Licensee MDPI, Basel, Switzerland. This article is an open access article distributed under the terms and conditions of the Creative Commons Attribution (CC BY) license (https:/ / creativecommons.org/licenses/by/ $4.0 /)$.

\begin{abstract}
Quercus rotundifolia bark was studied regarding anatomical, chemical, and antioxidant properties from trees in two sites in southern Portugal and are here reported for the first time. The general structure and anatomy of $Q$. rotundifolia bark showed a rhytidome with sequential undulated and anastomosed periderms with a small proportion of cork, while the phloem included broad rays with strong cell sclerification, groups of sclereids with embed large prismatic crystals, and abundant druses in parenchyma cells. The mean chemical composition was $15.5 \%$ ash, $1.6 \%$ dichloromethane extractives, $6.4 \%$ ethanol and $9.3 \%$ water extractives, 3.0\% suberin, 30.5\% total lignin, and 33.8\% carbohydrates. Carbohydrates included mainly glucose $(50.7 \%$ of total monomers) and xylose $(23.8 \%)$, with uronic $(3.0 \%)$ and acetic acids $(1.0 \%)$. Suberin was mainly composed of $\omega$-hydroxyacids ( $48.0 \%$ of all compounds) and $\alpha, \omega$-diacids (19.5\%). The main compounds found in the lipophilic extracts were triterpenes $(43.6 \%-56.2 \%$ of all compounds) and alkanoic acids $(32.7 \%-41.7 \%)$. Phenolic content was high especially in the ethanol extracts, ranging from 219.5-572.9 mg GAE/g extract and comprising 162.5-247.5 CE/g extract of flavonoids and 41.2-294.1 CE/g extract of condensed tannins. The extracts revealed very good antioxidant properties with $\mathrm{IC}_{50}$ values of $4.4 \mu \mathrm{g}$ ethanol extract $/ \mathrm{mL}$ and $4.7 \mu \mathrm{g}$ water extract $/ \mathrm{mL}$. Similar anatomical, chemical, and antioxidant characteristics were found in the bark from both sites. The high phenolic content and excellent antioxidant characteristics of polar extracts showed holm oak barks to be a promising natural source of antioxidants with possible use in industry and pharmaceutical/medical areas.
\end{abstract}

Keywords: holm oak; non-wood forest products; bark anatomy; polar extracts; bioactivity; antioxidants

\section{Introduction}

The use of bark evolved from ancient times to present day, expanding according to the different socioeconomic contexts, as well as the scientific and technological advances. Barks show a large diversity and have a high chemical compound richness, namely regarding extractives such as sterols, terpenes, and a large number of different phenolic compounds, allowing application in medicine and pharmacy, adhesives, formaldehyde scavengers, and antioxidants.

Quercus rotundifolia Lam., generally known as holm oak ("azinheira" in Portuguese and "encina" in Spanish) due to its leaf's resemblance to Ilex aquifolium L. (the common European holly used in Christmas), is taxonomically complex and either recognized as a separate species or subspecies (Q. ilex subesp. ballota (Desf.) Samp. or Q. ilex subesp. rotundifolia (Lam.) O. Schwarz ex Table Morais) belonging to the subsection Sclerophyllodrys O. Schwartz [1,2]. It is naturally distributed in southern Europe (Portugal, south and southeast Spain) and northwestern Africa (mainly Morocco) in the western Mediterranean basin. Quercus rotundifolia is the main evergreen oak, besides $Q$. suber, which is characteristic of the Mediterranean typical agrosilvopastoral system in Portugal ("montado") and Spain ("dehesa"), that populates these savanna-like ecosystems. Quercus rotundifolia is found 
in a wide variety of soils and its drought-tolerant capacity has been well emphasized in literature due to a xylem plasticity showing greater resistance than the co-occurring evergreen $Q$. ilex L. or $Q$. ilex subsp. ilex L. and deciduous $Q$. faginea species (e.g., [3,4]). Several ecophysiological and biochemical studies have referred to the seedling and root performances, the stomatal responses, and the antioxidant systems as combined strategies to increase drought-tolerance of the holm oak under the Mediterranean-type climate (e.g., [5-7]). Those studies are important for the species' conservation and sustainability due to climate change and the potential decline of this forest system. However, most of the studies have dealt with $Q$. ilex or $Q$. ilex subesp. ilex, which are morphologically and genetically distinct from $Q$. rotundifolia and differently distributed $[1,8,9]$.

Most reports on $Q$. rotundifolia have been historically related with the establishment, management, and maintenance of the agrosilvopastoral system. Its ecological importance is well acknowledged, while the economic importance is mainly related with acorn production for animal grazing. In fact, the Q. rotundifolia acorns are described as the sweetest among oaks, already used since the 18th century in the Iberian Peninsula as nuts associated with poor diets, and now gaining high value as a source of consumable flour within the local economies [10]. Another main economic interest of $Q$. rotundifolia, one that has prevailed for a long time, is related with the high density and the excellent calorific properties of the wood for charcoal production and firewood uses, for which the wood obtained from thinning or pruning operations is almost exclusively used [11].

Considering Quercus barks as potential resources, the case of $Q$. suber bark is highlighted due to the extensive cork layer in its periderm, which allows for sustainable cork production with major economic importance [12]. Cork has a unique set of properties, given by the material's structural and chemical features, which are at the base of a dedicated industrial sector producing known cork products worldwide [13]. Quercus cerris [14] and Q. variabilis [15], among other cork rich species [16], are also potential sources of cork, even if structural inhomogeneity must be taken into consideration before processing. However, the barks of the majority of the other oaks are not cork-rich and are referred in the literature as polyphenol-rich materials, showing excellent antioxidative capacity, namely with antimicrobial, anti-inflammatory, and antitumoral properties. Yet, little has been studied for most of the species, with some exceptions for Q. infectoria, Q. coccifera, and Q. crassifolia [17]. In general, most interests are related with the bark phenolic compounds, such as flavonoids and tannins [18]. In fact, the first and ancient sources for tanning included Quercus spp. barks in western Europe, before being replaced by non-natural agents [1,19]. While for the most valued oaks, $Q$. petraea and $Q$. robur, from which wood is the main product, a high phenolic content in bark extracts was confirmed (e.g., [20-22]) and the potential of other lesser-known oaks, such as $Q$. faginea, has also been acknowledged [23]. The lipophilic content of bark is also of high interest due to its application in food- and medicine-related areas, and compounds such as sterols and triterpenes were also found, for example, in $Q$. faginea bark [23]. Furthermore, recent studies on the potential for biorefineries of oak barks highlighted Q. rubra, Q. laurina, and Q. crassifolia due to their chemical compositions (e.g., [24-26]). This diversity of organic and inorganic components is related with their structural and physiological functions, namely the phenol-based compounds for oak wood durability and biotic defense of oak trees [27].

For the valorization and assessment of the potential of barks, it is important to have specific information on their structure and anatomy, in the line of what has been studied by this research group for Q. faginea [28] and Q. cerris [29]. Regarding holm oak, its bark anatomy was not studied yet, with exceptions for the first works of the periderms of $Q$. ilex $x Q$. suber hybrids [30], describing a rhytidome with successive and thin phellems. Studies dealing with the chemical properties are not available, with the exception of studies for the bark of $Q$. ilex L. reporting its antibacterial activity [31] and suitability for pollution biomonitoring [32]. The bark potential of $Q$. rotundifolia has not yet been analyzed and, to our knowledge, the present study is the first to characterize, in detail, the holm oak bark structure, anatomy, chemical composition, and antioxidant properties, also calling 
attention to the anatomical and chemical variability of the bark of different trees at two sites. These results will contribute to more knowledge-based decision-making on future $Q$. rotundifolia management within its natural and geographic distribution range as part of the montado.

\section{Material and Methods}

\subsection{Sites and Sampling}

The bark samples were obtained from $Q$. rotundifolia trees selected along the species' natural distribution in Portugal—at the Perímetro Florestal da Contenda $\left(38^{\circ} 03^{\prime} \mathrm{N}, 07^{\circ} 06^{\prime} \mathrm{W}\right.$; 450 m altitude; site 1), a stand under the management of the public institute ICNF (Instituto da Conservação da Natureza e das Florestas), and at Mora (38 $56^{\prime} \mathrm{N}, 8^{\circ} 7^{\prime} \mathrm{W} ; 130 \mathrm{~m}$; site 2), a privately owned stand. For each site, legal permission was given to the sampling by ICNF. At both sites, the holm oak trees (hereafter referred to $Q$. rotundifolia, except if the opposite is mentioned) are sparse, the stands are unevenly aged and holm oaks are mixed with the dominant $Q$. suber trees. At each site, five trees were randomly selected and were sampled during February 2018 at site 1 and during October 2017 at site 2. The sampled trees are characterized in Table 1 . The trees showed the characteristic holm oak architecture with an average of $7 \mathrm{~m}$ of tree height, a clear stem below branching of $1.6 \mathrm{~m}$, and a $26.5 \mathrm{~cm}$ diameter at breast height (b.h., i.e., at $1.30 \mathrm{~m}$ above ground). Stand year plantation was not known and annual rings were not easily distinguishable in stem cross-sections (data not published). However, tree age was approximately estimated at 50-60 years and deemed to be similar at both sites. A $2 \mathrm{~cm}$ thick cross-sectional disc was cut from each tree at b.h. Bark thickness was measured along two cross-diameters. The samples of bark were manually removed, air-dried, and separated in two sets, one for anatomical characterization of the wood and the other for chemical analysis.

Table 1. Characteristics of the studied Quercus rotundifolia trees from two sites (mean and standard deviation of five trees, min and max in parenthesis).

\begin{tabular}{|c|c|c|}
\hline & Site 1 & Site 2 \\
\hline Tree age (years) * & $44 \pm 14(25-65)$ & $49 \pm 18(25-65)$ \\
\hline Total tree height (m) & $7.2 \pm 0.5(6.7-7.7)$ & $6.1 \pm 2.1(3.9-9.2)$ \\
\hline Stem height (m) & $1.6 \pm 0.2(1.4-1.8)$ & $1.6 \pm 0.4(1.3-1.7)$ \\
\hline Diameter $(\mathrm{cm}) * *$ & $27.0 \pm 2.2(24.4-29.4)$ & $25.9 \pm 6.9(17.3-32.9)$ \\
\hline Bark thickness (mm) & $11.5 \pm 2.5(8.3-15.2)$ & $11.7 \pm 1.7(9.9-14.5)$ \\
\hline Rhytidome thickness (mm) & $4.9 \pm 1.2(2.8-6.3)$ & $5.4 \pm 1.6(2.5-6.7)$ \\
\hline
\end{tabular}

\subsection{Cellular Structure Characterization}

The macroscopic observations were made on the bark sample cross-section after surface sanding (P 1000) using a modular stereomicroscope (Leica MZ6, Leica Microsystems Ltd., Heerburg, Germany) coupled to a digital camera (Leica DC320, Leica Microsystems Ltd., Heerburg, Germany). For the microscopic observations, the bark samples were impregnated with polyethylene glycol (DP 1500), and transverse and longitudinal microscopic sections of approximately $17 \mu \mathrm{m}$ thickness were prepared with a sliding microtome (Leica SM 2400, Leica Microsystems Nussloch GmbH, Nussloch, Germany) using adhesive for sample retrieval. The sections were stained with a double staining of chrysodine/astra blue and Sudan 4 was used for selective staining of suberin. Individual bark specimens were also macerated for observation. Slide preparation and maceration followed standard procedures described in previous works [28]. Phloem and rhytidome were measured at two random intact points using image analysis systems (Leica Qwin Pro, v 3.5.0). Qualitative and quantitative observations were made using light microscopy (Nikon Microphot-FXA, Nikon, Japan). Bark terminology followed the IAWA List of Microscopic Bark Features [33]. 


\subsection{Chemical Summative Analysis}

The bark samples of each tree were ground separately in a cutting mill (Retsch SM 2000, Retsch $\mathrm{GmbH}$, Haan, Germany) using an output sieve of $10 \mathrm{~mm} \times 10 \mathrm{~mm}$, followed by one of $2 \mathrm{~mm} \times 2 \mathrm{~mm}$, and fractionated with a vibratory system with standard sieves (Retsch AS 200, Retsch GmbH, Haan, Germany). The 40-60 mesh (0.425-0.250 mm) fractions were used for chemical analysis. The summative chemical analysis included determination of ash; extractives in dichloromethane, ethanol, and water; suberin; Klason and acid-soluble lignin; and the monomeric composition of polysaccharides. Determinations were made in duplicate samples. The methods followed the procedures adopted in our laboratory for bark chemical characterization (e.g., $[23,34]$ ) and can be briefly described as follows. The ash content was determined by incinerating $2.0 \mathrm{~g}$ of each sample at $525^{\circ} \mathrm{C}$ overnight and weighing the residue, reported as percentage of the original samples (Tappi $211 \mathrm{om}-02$ ). The extractives were determined with procedures adapted from Tappi $204 \mathrm{~cm}-97$, performed in a Soxhlet system with dichloromethane, ethanol, and water under reflux successively, after which the content was calculated for each solvent by mass difference of the ovendried solid residue and reported as a percentage of the original sample. The suberin content was determined by methanolysis for depolymerization using $1.5 \mathrm{~g}$ of the sample of extractive-free material and is expressed as a percentage of the initial dry mass [35]. The lignin content was analyzed from the extracted and desuberinized samples by acid hydrolysis. Klason lignin was determined as the mass of the solid residue after drying at $105^{\circ} \mathrm{C}$ (Tappi T $222 \mathrm{om}-02$ ). The acid-soluble lignin was determined by measuring the UV absorbance (TAPPI Useful Method UM 250). The remaining acid solution was kept for sugar analysis. The carbohydrates were calculated based on the amount of the neutral sugar monomers (rhamnose, arabinose, xylose, galactose, mannose, and glucose) and uronic acids (galacturonic and glucuronic acids) released by total hydrolysis, after derivatization as alditol acetates and separation by high-pressure ion-exchange chromatography with a pulsed amperometric detector (HPIC-PAD). The content of acetic acid was also determined in the hydrolysate using high-pressure ion-exclusion chromatography with a UV/visible detector (HIPCE-UV).

\subsection{Composition and Antioxidant Activity of Polar Extracts}

The ethanol and water extracts were obtained by successive Soxhlet extraction and analyzed in relation to total phenolics (TPC), flavonoids (FC), and condensed tannin (TC) content, as previously described [23]. Each assay was performed at least three times and at least three independent replicates were prepared for each standard and sample. The FolinCiocalteu method was used for TPC determination, using gallic acid as standard, and the results were reported as $\mathrm{mg}$ gallic acid equivalents (GAE)/g of dried bark extract. The $\mathrm{AlCl}_{3}$ colorimetric assay was used for the FC determination, using catechin as standard, with the results expressed as $\mathrm{mg}$ of catechin equivalents (CE)/g of dried bark extract. TC was determined by the vanillin-sulfuric acid assay, using catechin as standard, and the results are expressed as $\mathrm{mg}$ catechin equivalents (CE)/g of dried bark extract. The antioxidant activity of the ethanol and water extracts was determined using two methods-ferric reducing/antioxidant power (FRAP), which measures the sample's ferric reducing power, and 2,2-diphenyl-1-picryhydrazyl (DPPH), which measures the free radical scavenging capacity, as previously described [23]. FRAP is expressed as Mmol Trolox equivalents/g dry mass and the DPPH is expressed in terms of the amount of extract required to reduce $50 \%$ of the DPPH concentration $\left(\mathrm{IC}_{50}\right)$ and Trolox equivalents on a dry extract base (TEAC).

\subsection{Composition of Lipophilic Extracts}

Aliquots of the dichloromethane (DCM) extracts $(5 \mathrm{~mL})$ were taken, evaporated under $\mathrm{N}_{2}$ flow, and dried at room temperature under vacuum overnight. For the GC-MS analysis, one aliquot from the DCM extracts $(2 \mathrm{mg}$ ) was derivatized to trimethylsilyl ethers/esters (TMS) with $100 \mu \mathrm{L}$ of pyridine (Sigma-Aldrich, St. Louis, MO, USA) and $100 \mu \mathrm{L}$ of BSTFA (N,O-bis(trimethylsilyl)trifluoroacetamide with $1 \%$ trimethylchlorosilane, Sigma-Aldrich, 
St. Louis, MO, USA) at $60{ }^{\circ} \mathrm{C}$ for $30 \mathrm{~min}$. After cooling at room temperature, the extracts were injected in splitless mode in a GC-MS (Agilent 7890 A-5975C MSD, Santa Clara, CA, USA) with an autoinjector and a high-temperature capillary column (Zebron $5 \mathrm{H} \mathrm{T}$, $30 \mathrm{~m} \times 0.25 \mathrm{~mm} \times 0.1 \mu \mathrm{m}$, Anaheim, CA, USA) using He as carrier gas at a constant flow of $1 \mathrm{~mL} / \mathrm{min}$. The injector temperature was $280^{\circ} \mathrm{C}$ and the oven was programmed with an initial temperature of $100{ }^{\circ} \mathrm{C}(1 \mathrm{~min}), 10^{\circ} \mathrm{C} / \mathrm{min}$ to $250{ }^{\circ} \mathrm{C}(1 \mathrm{~min}), 8{ }^{\circ} \mathrm{C} / \mathrm{min}$ to $350{ }^{\circ} \mathrm{C}(5 \mathrm{~min})$, and $8{ }^{\circ} \mathrm{C} / \mathrm{min}$ to $380{ }^{\circ} \mathrm{C}(5 \mathrm{~min})$. The MS source conditions were MSD transfer-line temperature maintained at $330{ }^{\circ} \mathrm{C}$, the $\mathrm{MS}$ source at $230{ }^{\circ} \mathrm{C}$, the quadrupole at $150{ }^{\circ} \mathrm{C}$, and the electron ionization energy at $70 \mathrm{eV}$. The electronic impact mass spectra (EIMS) were taken over a range of $\mathrm{m} / \mathrm{z}$ 40-950. For semi-quantification analysis, the GC-MS was externally calibrated with standards (hexadecanoic acid and asiatic acid) that are representative of the major families of the lipophilic extracts (saturated fatty acids and triterpenes, respectively). The respective multiplication factors needed to acquire a correct quantification of the peak areas were calculated as an average of three GC-MS runs. The compounds are expressed as a \% of each peak in TIC. Each aliquot was injected and duplicated. The identification of the compounds (as TMS derivatives) was based on comparisons with standards, Wiley 6 and NIST libraries data, and interpretation of mass spectrometric fragmentation patterns.

\subsection{Composition of Suberin}

Aliquots of the dichloromethane extracts $(5 \mathrm{~mL})$ from the suberin depolymerization reaction were taken, evaporated under $\mathrm{N}_{2}$ flow, and dried at room temperature under vacuum overnight. For the GC-MS analysis, one aliquot from the DCM extracts (1 mg) was derivatized to trimethylsilyl ethers/esters (TMS) with $100 \mu \mathrm{L}$ of pyridine (Sigma-Aldrich, St. Louis, MO, USA) and $100 \mu \mathrm{L}$ of BSTFA (N,O-bis(trimethylsilyl) trifluoroacetamide with $1 \%$ trimethylchlorosilane, Sigma-Aldrich, St. Louis, MO, USA) at $60{ }^{\circ} \mathrm{C}$ for $30 \mathrm{~min}$. The subsequent procedures are described above.

\subsection{Statistical Analysis}

All results are expressed as mean and standard deviation. The significance of differences $(p<0.05)$ among the corresponding mean values was determined by one-way analysis of variance (ANOVA) using the SPSS statistical software (version 26).

\section{Results}

\subsection{Structure and Anatomy}

The external appearance of the bark of $Q$. rotundifolia was finely square fissured. It was similar in the trees at both sites, with $11.6 \mathrm{~mm}$ mean width, including equally distributed rhytidome and secondary phloem (Table 1 and Figure 1).
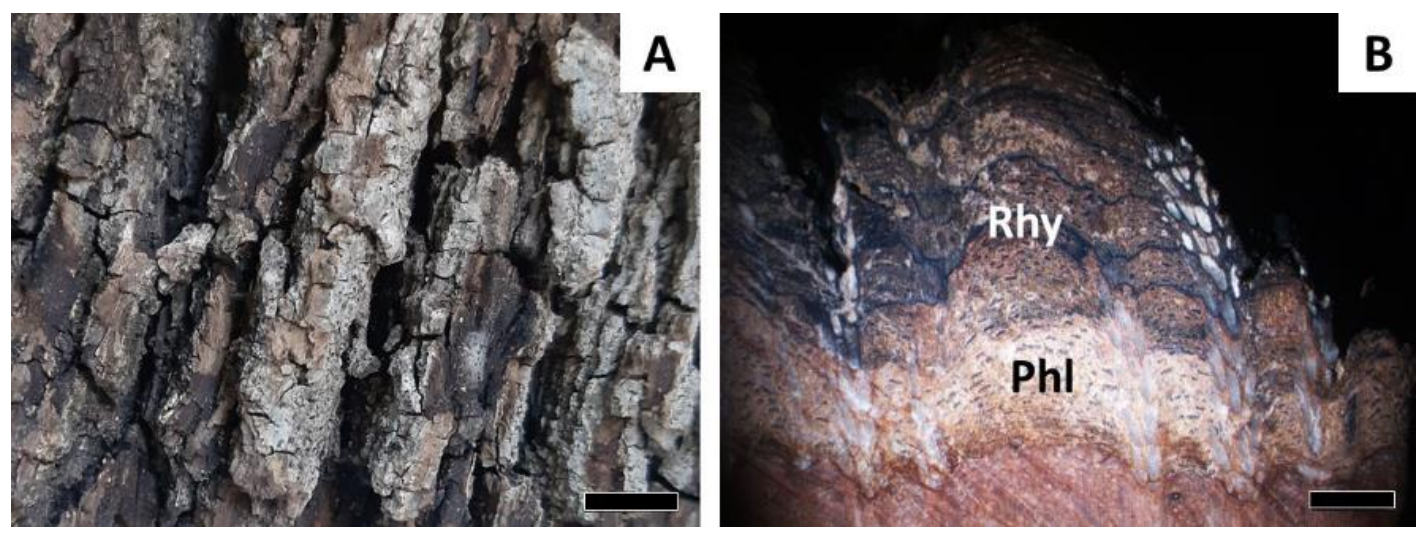

Figure 1. Bark structure of Quercus rotundifolia. (A) General aspects of the rhytidome; (B) phloem (Phl) and rhytidome (Rhy) on the transverse section. Scale bar: $\mathrm{A}=1 \mathrm{~cm} ; \mathrm{B}=2 \mathrm{~mm}$. 
The rhytidome of $Q$. rotundifolia was persistent, with $5.1 \mathrm{~mm}$ mean width (Table 1 and Figure 1), and composed of various periderms and dead secondary phloem between them (Figure 2A-C). Its qualitative anatomy did not differ among trees. The sequential periderms formed thin and undulated layers that occasionally anastomosed (Figure 2A); in each periderm, the phellem (cork) was poorly developed, comprising layers (<10 layers) of radially flattened cells arranged into a more or less distinct radial pattern with thin suberized walls or, sometimes, lignified thick walls. The phelloderm consisted of a few layers (1-3) of rectangular to round cells, also with radial alignment (Figure 2D). Both phellem and phelloderm cells may be filled with dark contents, presumably phenolic compounds. The phellogen, which gives rise to the phellem outside and phelloderm inside, is, in general, difficult to recognize but sometimes could be observed as rectangular and thin-walled cells in cross section (Figure 2D).
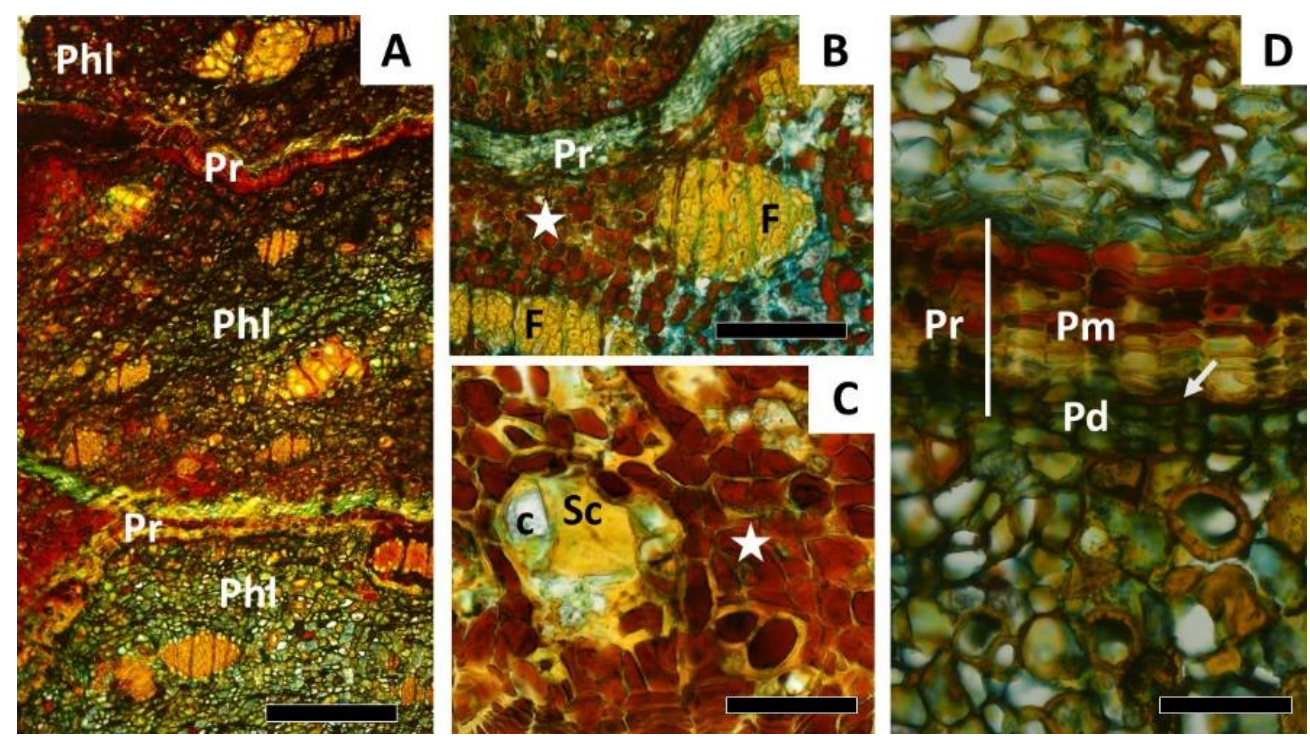

Figure 2. Transverse section of the bark of Quercus rotundifolia. (A) Rhytidome includes various periderms (Pr) and dead secondary phloem (Phl) between them; (B) portions of rhytidome-periderm (Pr), fibers (F), and parenchyma cells filled with extractives (asterisk); (C) sclereid with embedded crystal (c) and extractives in radial and axial parenchyma cells (asterisk); (D) a detailed view of the periderm with 7 cells of phellem (Pm) and 2-3 cells of phelloderm and the phellogen (arrow). Scale bar: $\mathrm{A}=200 \mu \mathrm{m} ; \mathrm{B}=130 \mu \mathrm{m} ; \mathrm{C}=80 \mu \mathrm{m} ; \mathrm{D}=50 \mu \mathrm{m}$.

The secondary phloem (Figures 3-5) included the conducting and nonconducting phloem, with a gradual transition between these two layers. The phloem was nonlayered and the growth rings were difficult to recognize.

The conducting phloem near the vascular cambium represented a narrow portion of the entire phloem (Figure 3A) and consisted of the functional sieve tube elements and companion cells (conducting tissue), the axial parenchyma (storied tissue), rays (storage/transversal conduction), and fibers (mechanical support). The sieve tubes elements were thin, nonlignified walled cells with round to irregular shape in transverse view and were mostly tangentially or radially grouped (Figure 3D). The sieve tube elements had compound and inclined sieve plates and numerous lateral sieve areas (Figure 3E). The companion cells were recognized in transversal sections (Figure 3D). The axial parenchyma cells were nonlignified and thin-walled with a round shape of irregular size in transverse view and appeared as thin strands of a few cells located between fibers and interspersed with sieve elements (Figures 3D and 4B). The fibers were arranged in small groups as discontinuous tangential bands crossed by thin rays (Figure $2 \mathrm{C}$ ); fibers were thick-walled and lignified, accompanied by chambered crystalliferous cells. (Figures 4A,B and 5A). The rays were comprised of two types (Figures $3 \mathrm{~A}-\mathrm{C}, 4 \mathrm{~B}$ and $5 \mathrm{~A}, \mathrm{~B}$ ): uniseriate rays and broad rays (multiseriate, up to 20 cells wide and $>100$ cells high), both homocel- 
lular with procumbent cells (Figure 5C). These broad rays often protrude into the xylem (Figure 3B). Sclerification of radial parenchyma cells occurred mostly in these fused broad rays (Figures 3A,B and 5B), early in the conducting phloem near the cambium (Figure 3B).
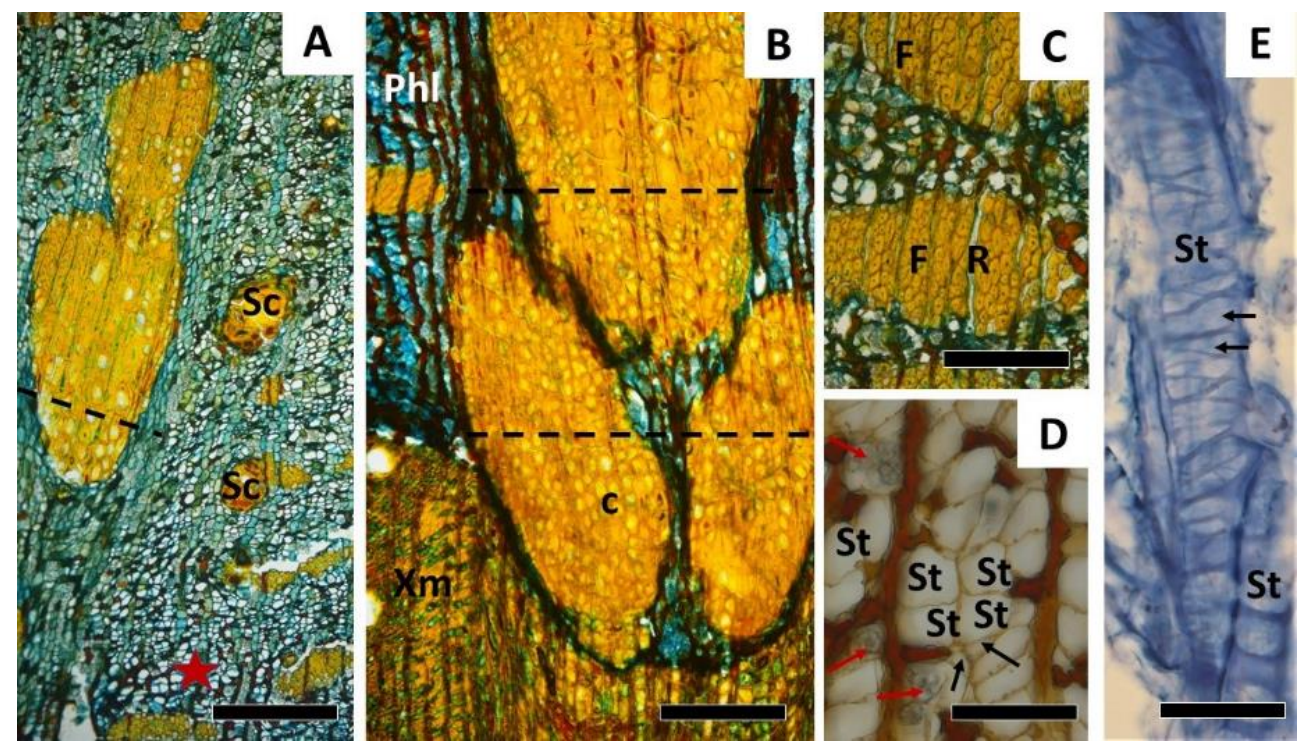

Figure 3. Transverse section of the secondary phloem of Quercus rotundifolia. (A) Nonconducting and conducting phloem (asterisk), large rays (-) with sclerified ray parenchyma cells; spherical groups of sclereids (Sc); (B) the broad rays (-) of the phloem (Phl) protrude into the xylem (Xm); crystals (c); (C) fibers (F) in tangential groups transversed by the thin rays (R); (D) sieve tube elements (St) with companion cells (black arrows); druses (red arrows); (E) sieve tube elements (St) with many lateral sieve areas (arrows). Scale bar: $A=200 \mu \mathrm{m} ; \mathrm{B}=200 \mu \mathrm{m} ; \mathrm{C}=130 \mu \mathrm{m} ; \mathrm{D}=50 \mu \mathrm{m} ; \mathrm{E}=50 \mu \mathrm{m}$.
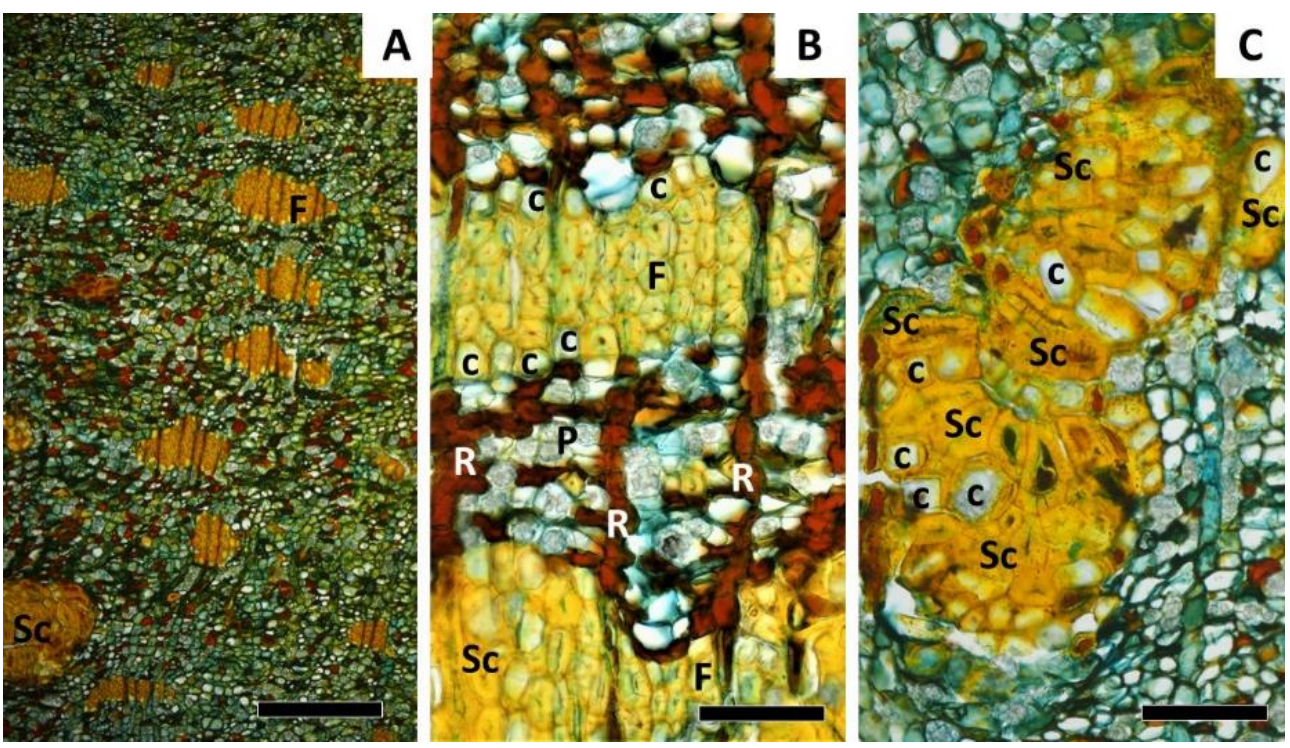

Figure 4. Transverse section of the nonconducting secondary phloem of Quercus rotundifolia. (A) Tangential groups of fibers $(\mathrm{F})$ and groups of sclereids $(\mathrm{Sc})$. (B) fibers $(\mathrm{F})$ in tangential groups bordered by crystals (c); thin rays filled with extractives (R); nonlignified axial parenchyma cells (P) and sclereids (Sc). (C) Group of sclereids (Sc); these cells are strongly lignified with thickened walls and sometimes enclose a large prismatic crystal (c) and phenolic compounds (dark staining). Scale bar: $A=200 \mu \mathrm{m}$; $\mathrm{B}=80 \mu \mathrm{m} ; \mathrm{C}=65 \mu \mathrm{m}$. 

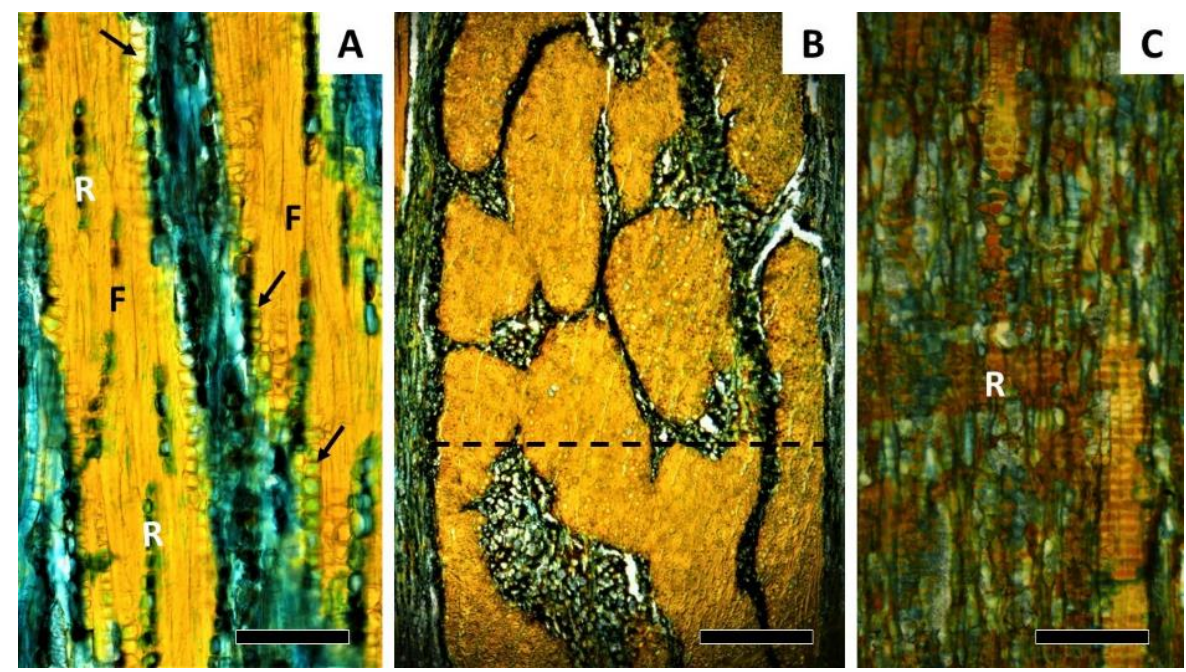

Figure 5. Longitudinal sections of secondary phloem of Quercus rotundifolia (tangential A,B and radial C, sections). (A) Uniseriate rays (R), fibers (F) bordered by a series of crystalliferous cells (arrows). (B) A large ray (-) with strongly lignified parenchyma cells. (C) Rays of homogeneous type (R) with procumbent cells filled with contents of brown color. Scale bar: $A=65 \mu \mathrm{m} ; B=300 \mu \mathrm{m} ; C=160 \mu \mathrm{m}$.

The nonconducting tissue started with the collapse of the sieve elements. At this point, the structure of the secondary phloem became disorganized with distortion and expansion of cells with subsequent sclerification, associated with the dilatation growth. Sclereids and fiber-sclereids (Figure 6A) with thick and heavily lignified cells walls appeared and often formed spherical or irregular prominent groups (Figures $3 \mathrm{~A}$ and $6 \mathrm{~A}-\mathrm{C}$ ), dispersed in the phloem adjacent to the fibers and near or within the broad rays. Abundant sclerification of parenchyma cells occurred in the outer portion of phloem near the inner periderm.
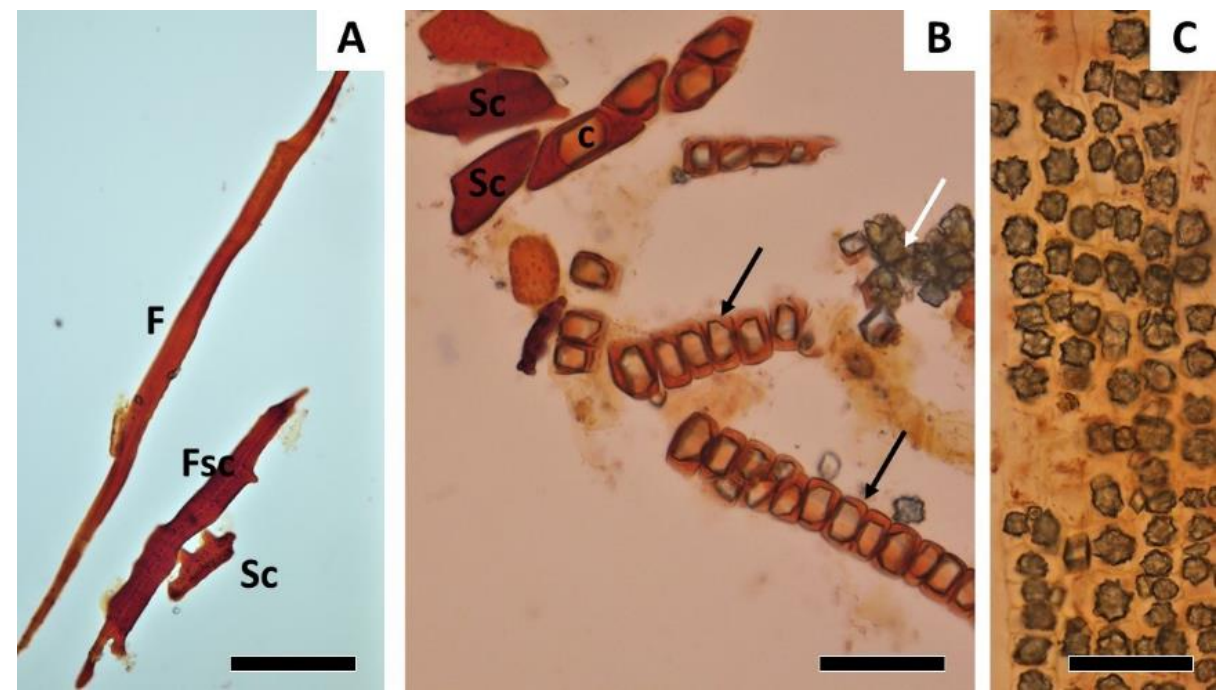

Figure 6. Individualized cells of the bark of Quercus rotundifolia. (A) Sclerenchyma tissue: secondary fibers (F), fibrosclereid (Fsc), and sclereid (Sc); (B) sclereid (Sc), sometimes with a prismatic crystal (c), series of parenchyma crystalliferous cells (black arrow), and druses (white arrow); (C) innumerous druses in nonlignified parenchyma cells. Scale bar: $A=80 \mu \mathrm{m} ; \mathrm{B}=50 \mu \mathrm{m} ; \mathrm{C}=50 \mu \mathrm{m}$.

Crystals, presumably of calcium oxalate, were abundant through all the bark, mostly present as abundant druses (Figures 3D and $6 \mathrm{~B}, \mathrm{C}$ ) in axial parenchyma adjacent to sieve tube elements and as prismatic crystals in both sclereids (one large crystal/sclereid, Figures 2C, 4C and 6B) and axial parenchyma cells, e.g., crystalliferous parenchyma (Figure 6B), which bordered the fiber groups (Figures 4B and 5A). Abundant phenolic 
compounds were observed by dark color staining in the secondary phloem and rhytidome e.g., axial and ray parenchyma cells, in the sclereids, phellem, and phelloderm cells (Figures $2 \mathrm{~B}-\mathrm{D}$ and $4 \mathrm{~A}-\mathrm{C}$ ).

\subsection{Chemical Composition}

The summative chemical compositions of the Q. rotundifolia bark samples, from the two sites, are summarized in Table 2 . The mean composition was (in \% of the oven dry bark) $15.5 \%$ ash, $17.2 \%$ extractives, $3.0 \%$ suberin, $30.5 \%$ lignin, and $33.8 \%$ polysaccharides. Q. rotundifolia bark showed a high content of extractives of $15.1 \%$ (site 2) and $19.3 \%$ (site 1 ). The main contribution came from polar compounds solubilized by ethanol and water, representing $88 \%$ and $93 \%$ of the total extractives, respectively, for barks from trees of site 2 and 1; the non-polar compounds extracted by dichloromethane corresponded only to an average of $10.2 \%$ of the total extractives. Suberin content was low at $2.9 \%$ (site 2) and $3.1 \%$ (site 1), while the total lignin content was relatively high at $29.1 \%$ (site 1 ) and $31.8 \%$ (site 2). The ash content of $Q$. rotundifolia bark samples was particularly high. Between sites, a statistically significant difference was detected only in the content of dichloromethane and ethanol extractives.

Table 2. Chemical composition (\% of o.d. mass) of Quercus rotundifolia bark sampled at b.h. from two sites (mean of five trees and standard deviation).

\begin{tabular}{cccc}
\hline & Site $\mathbf{1}$ & Site 2 & $p$-Value \\
\hline Ash & $14.9 \pm 3.1$ & $16.0 \pm 2.3$ & 0.343 \\
Extractives, total & $19.3 \pm 3.5$ & $15.1 \pm 0.8$ & 0.001 \\
Dichloromethane & $1.3 \pm 0.3$ & $1.8 \pm 0.3$ & 0.001 \\
Ethanol & $9.1 \pm 3.5$ & $3.7 \pm 2.1$ & 0.000 \\
Water & $8.9 \pm 1.0$ & $9.6 \pm 1.5$ & 0.257 \\
Suberin & $3.1 \pm 0.4$ & $2.9 \pm 0.6$ & 0.440 \\
Lignin, total & $29.1 \pm 3.5$ & $31.8 \pm 3.6$ & 0.085 \\
\hline Klason lignin & $25.9 \pm 3.6$ & $28.6 \pm 3.7$ & 0.092 \\
Soluble lignin & $3.3 \pm 0.2$ & $3.3 \pm 0.3$ & 0.985 \\
Polysaccharides * & $33.6 \pm 2.5$ & $34.2 \pm 2.6$ & 0.157 \\
\hline
\end{tabular}
* by difference.

The carbohydrate composition is summarized in Table 3 in regards to the proportion of neutral monosaccharides, acetates, and uronic acids. The major monosaccharide was glucose, corresponding to $52 \%$ and $49 \%$ of the total monomers, while xylose was the dominant non-cellulosic sugar with $24 \%$; arabinose, galactose, and rhamnose were also present $(9.3 \%, 5.4 \%$, and $3.3 \%$, respectively). Uronic acids were also present, representing $5.9 \%$ of the total content of monomers as well as acetyl groups (1.0\%). The carbohydrate composition was similar at both sites.

Table 3. Composition of polysaccharides (\% of total monomers) determined after acid hydrolysis as neutral monosaccharides and uronic and acetic acids of Quercus rotundifolia bark sampled at b.h. from two sites (mean of five trees and standard deviation).

\begin{tabular}{ccc}
\hline & Site $\mathbf{1}$ & Site $\mathbf{2}$ \\
\hline Rhamnose & $2.8 \pm 0.6$ & $3.7 \pm 0.9$ \\
Arabinose & $8.9 \pm 0.8$ & $9.6 \pm 2.1$ \\
Galactose & $5.2 \pm 0.4$ & $5.6 \pm 1.2$ \\
Glucose & $51.9 \pm 1.8$ & $49.4 \pm 2.5$ \\
Xylose & $24.0 \pm 1.9$ & $23.5 \pm 3.0$ \\
Mannose & $0.7 \pm 0.2$ & $0.9 \pm 0.6$ \\
Galacturonic acid & $5.3 \pm 0.6$ & $6.3 \pm 1.0$ \\
Glucuronic acid & $0.02 \pm 0.04$ & $0.2 \pm 0.1$ \\
Acetyl groups & $1.1 \pm 0.1$ & $0.8 \pm 0.2$ \\
\hline
\end{tabular}




\subsection{Polar Extracts Composition}

The results for TPC, FC, and TC, as well as the antioxidant activity of the extracts obtained successively with ethanol and water, are shown in Table 4. The ethanol extracts contained much higher values of phenolics, flavonoids, and tannins than the subsequent water extracts. The bark ethanol extracts had a high proportion of phenolic compounds (572.8 mg GAE/g extract; $3.7 \mathrm{~g} \mathrm{GAE/g} \mathrm{dry} \mathrm{bark),} \mathrm{in} \mathrm{which} \mathrm{flavonoids} \mathrm{and} \mathrm{condensed}$ tannins constituted the major classes (247.6 mg CE/g extract and $294.1 \mathrm{mg} \mathrm{CE} / \mathrm{g}$ extract, respectively). The bark water extracts contained a much lower amount of phenolic compounds: total phenolics $219.5 \mathrm{mg} \mathrm{GAE} / \mathrm{g}$ of extract, flavonoids $162.5 \mathrm{mg} \mathrm{CE} / \mathrm{g}$ of extract, and condensed tannins $41.2 \mathrm{mg} \mathrm{CE} / \mathrm{g}$ of extract. Significant differences were found between sites for the ethanol and water extracts.

Table 4. Composition and antioxidant capacity of ethanol and water extracts of Quercus rotundifolia bark sampled at b.h. of trees in two sites (mean of five trees and standard deviation).

\begin{tabular}{cccc}
\hline & Site 1 & Site 2 & $p$-Value \\
\hline Ethanol extractives & & & \\
Total phenolics (mg GAE/g extract) & $561.7 \pm 77$ & $583.9 \pm 58.6$ & 0.222 \\
Total flavonoids (mg CE/g extract) & $173.8 \pm 69.6$ & $321.3 \pm 28.7$ & 0.000 \\
Condensed tannins (mg CE/g extract) & $115.8 \pm 35.6$ & $472.3 \pm 189.3$ & 0.000 \\
Antioxidant capacity (mg TEAC/g extract) & $696.9 \pm 97.4$ & $1390.6 \pm 515.3$ & 0.000 \\
IC $_{50}$ values ( $\mu$ g extract/mL) & $5.8 \pm 0.9$ & $2.9 \pm 1.2$ & 0.000 \\
FRAP (mM TEAC/g extract) & $2.25 \pm 0.92$ & $6.33 \pm 3.34$ & 0.001 \\
\hline Water extractives & & & \\
Total phenolics (mg GAE/g extract) & $253.7 \pm 26$ & $185.3 \pm 40.2$ & 0.001 \\
Total flavonoids (mg CE/g extract) & $133.9 \pm 31$ & $191.0 \pm 60$ & 0.021 \\
\hline Condensed tannins (mg CE/g extract) & $44.3 \pm 12.1$ & $38.1 \pm 7.4$ & 0.177 \\
Antioxidant capacity (mg TEAC/g extract) & $1109.6 \pm 268.8$ & $770.9 \pm 247$ & 0.003 \\
IC 50 values ( $\mu$ g extract/mL) & $3.4 \pm 0.9$ & $5.9 \pm 1.9$ & 0.001 \\
FRAP (mM TEAC/g extract) & $1.54 \pm 0.25$ & $1.13 \pm 0.48$ & 0.028 \\
\hline
\end{tabular}

GAE: gallic acid equivalents; CE: catechin equivalents; TEAC: Trolox equivalent antioxidant activity; ${ }^{*} \mathrm{IC}_{50}$ Trolox in ethanol and water 3.3 and $3.6 \mu \mathrm{g}$ Trolox/mL, respectively.

The radical scavenging activities of the bark extracts corresponded to $\mathrm{IC}_{50}$ values of $4.4 \mu \mathrm{g}$ extract $/ \mathrm{mL}$ and $4.7 \mu \mathrm{g}$ extract $/ \mathrm{mL}$, respectively, for the ethanol and water extracts. The reducing ability of the ethanol extracts by the FRAP assay was, on average, $4.29 \mathrm{mM}$ Trolox/g of extract, while that of the water extracts was on average $1.34 \mathrm{mM}$ Trolox/g of extract. The antioxidant capacity and the reducing ability of the polar extracts were significantly different between sites.

\subsection{Lipophilic Extract Composition}

The compositions of the lipophilic extractives are presented in Table 5. Triterpenes and alkanoic acids were the major identified chemical classes, representing $43.7 \%-56.2 \%$ and $32.7 \%-41.7 \%$ of the total, respectively. Ursolic acid, betulinic acid, betulin, and oleanolic acid constituted the major triterpenes found; in the lipophilic extracts from Q. rotundifolia bark collected at site 1, ursolic, betulinic and oleanolic acids were much more common $(19.8 \%, 18.8 \%$, and $7.5 \%$, respectively), whereas betulin existed in higher amounts in the lipophilic extracts from $Q$. rotundifolia bark collected at site $2(10.3 \%)$. Among the alkanoic acids, the saturated acids predominated over the substituted acids, with, respectively, $23.7 \%-31.2 \%$ and $9.0 \%-10.4 \%$ of all compounds. Extracts from Q. rotundifolia barks from site 2 showed higher content in alkanoic acids (and lower triterpenes), and the major identified compounds were the hexadecenoic, docosanoic, and tetracosanoic acids, representing $10.6 \%, 6.5 \%$, and $5.2 \%$, respectively. Sterols represented between $2.6 \%$ and $7.4 \%$ of all compounds, whereas $\beta$-sitosterol was the most representative compound. Aromatics, alkanols, saturated $\alpha, \omega$-diacids, and $\omega$-hydroxyacids were also present, but in small 
amounts (below $1.4 \%$ ). Overall, $84.4 \%$ to $99.3 \%$ of the compounds were identified in the lipophilic $Q$. rotundifolia bark lipophilic extracts.

Table 5. Composition of dichloromethane extracts from Quercus rotundifolia bark sampled at b.h. from trees grown at two sites, in \% of the normalized peak areas in TIC (mean of five trees and standard deviation).

\begin{tabular}{|c|c|c|}
\hline Compounds & Site 1 & Site 2 \\
\hline Alkanols & $0.91 \pm 0.35$ & $1.48 \pm 0.50$ \\
\hline hexadecanol & $0.03 \pm 0.06$ & $0.17 \pm 0.05$ \\
\hline octadecanol & $0.00 \pm 0.00$ & $0.01 \pm 0.03$ \\
\hline docosanol & $0.36 \pm 0.17$ & $0.60 \pm 0.22$ \\
\hline tetracosanol & $0.37 \pm 0.16$ & $0.41 \pm 0.11$ \\
\hline heptatriacotanol & $0.15 \pm 0.17$ & $0.28 \pm 0.35$ \\
\hline Saturated alkanoic acids & $23.72 \pm 7.86$ & $31.24 \pm 10.21$ \\
\hline decanoic acid & $0.00 \pm 0.00$ & $0.02 \pm 0.04$ \\
\hline dodecanoic acid & $0.05 \pm 0.05$ & $0.19 \pm 0.06$ \\
\hline tetradecanoic acid & $0.61 \pm 0.31$ & $2.38 \pm 1.20$ \\
\hline pentadecanoic acid & $0.01 \pm 0.03$ & $0.07 \pm 0.07$ \\
\hline hexadecanoic acid & $9.68 \pm 3.65$ & $11.63 \pm 4.99$ \\
\hline heptadecanoic acid & $0.01 \pm 0.03$ & $0.08 \pm 0.08$ \\
\hline octadecanoic acid & $1.55 \pm 0.46$ & $2.34 \pm 0.85$ \\
\hline eicosanoic acid & $0.26 \pm 0.09$ & $0.26 \pm 0.13$ \\
\hline heneicosanoic acid & $0.10 \pm 0.07$ & $0.17 \pm 0.11$ \\
\hline docosanoic acid & $5.14 \pm 1.75$ & $5.25 \pm 2.93$ \\
\hline tricosanoic acid & $0.22 \pm 0.07$ & $0.46 \pm 0.20$ \\
\hline pentacosanoic acid & $0.00 \pm 0.01$ & $0.07 \pm 0.10$ \\
\hline tetracosanoic acid & $5.53 \pm 2.59$ & $7.54 \pm 2.41$ \\
\hline hexacosanoic acid & $0.55 \pm 0.42$ & $0.79 \pm 0.33$ \\
\hline Substituted alkanoic acids & $8.95 \pm 6.20$ & $10.43 \pm 5.63$ \\
\hline trans-9-hexadecenoic acid & $0.01 \pm 0.03$ & $0.09 \pm 0.09$ \\
\hline cis-9-hexadecenoic acid & $0.09 \pm 0.06$ & $0.08 \pm 0.13$ \\
\hline 9,12-octadecadienoic acid & $3.37 \pm 2.43$ & $3.22 \pm 1.85$ \\
\hline cis-9-octadecenoic acid & $5.38 \pm 5.23$ & $6.95 \pm 3.57$ \\
\hline trans-9-octadecenoic acid & $0.10 \pm 0.11$ & $0.09 \pm 0.11$ \\
\hline Saturated $\alpha, \omega$-diacids & $0.00 \pm 0.00$ & $0.10 \pm 0.14$ \\
\hline nonanedioic acid & $0.00 \pm 0.00$ & $0.09 \pm 0.12$ \\
\hline hexadecanedioic acid & $0.00 \pm 0.00$ & $0.01 \pm 0.02$ \\
\hline Saturated $\omega$-hydroxyacids & $0.10 \pm 0.16$ & $0.27 \pm 0.21$ \\
\hline 22-hydroxydocosanoic acid & $0.10 \pm 0.16$ & $0.27 \pm 0.21$ \\
\hline Sterols & $2.61 \pm 0.98$ & $7.39 \pm 1.30$ \\
\hline$\beta$-sitosterol & $2.46 \pm 0.90$ & $6.84 \pm 1.26$ \\
\hline 3,5-stigmastadien-7-one & $0.02 \pm 0.04$ & $0.12 \pm 0.17$ \\
\hline stigmasterol & $0.02 \pm 0.04$ & $0.04 \pm 0.08$ \\
\hline 4-stigmasten-3-one & $0.11 \pm 0.11$ & $0.32 \pm 0.07$ \\
\hline sitosteryl-3 $\beta$-D-glucopiranoside & $0.00 \pm 0.00$ & $0.07 \pm 0.14$ \\
\hline Terpenes/Terpenoids & $56.21 \pm 9.15$ & $43.66 \pm 14.23$ \\
\hline farnesol & $0.01 \pm 0.02$ & $0.00 \pm 0.00$ \\
\hline$\beta$-amyrin & $0.01 \pm 0.02$ & $0.24 \pm 0.53$ \\
\hline lupenone & $0.30 \pm 0.43$ & $0.30 \pm 0.24$ \\
\hline$\alpha$-amyrin & $0.02 \pm 0.04$ & $0.00 \pm 0.00$ \\
\hline lupeol & $1.46 \pm 1.15$ & $3.10 \pm 3.10$ \\
\hline erythrodiol & $2.22 \pm 2.12$ & $1.09 \pm 1.40$ \\
\hline friedelin & $1.84 \pm 4.01$ & $5.01 \pm 8.59$ \\
\hline friedelan-3-ol & $0.60 \pm 0.84$ & $0.11 \pm 0.24$ \\
\hline betulin & $1.74 \pm 3.54$ & $10.33 \pm 10.71$ \\
\hline
\end{tabular}


Table 5. Cont.

\begin{tabular}{ccc}
\hline Compounds & Site 1 & Site 2 \\
\hline oleanolic acid & $7.48 \pm 4.20$ & $4.06 \pm 1.72$ \\
ursolic acid & $19.85 \pm 12.15$ & $8.22 \pm 4.32$ \\
betulinic acid & $18.80 \pm 6.07$ & $9.58 \pm 5.80$ \\
betulinic aldehyde & $0.27 \pm 0.19$ & $0.52 \pm 0.35$ \\
hederagenin & $0.35 \pm 0.71$ & $0.08 \pm 0.12$ \\
maslinic acid & $0.93 \pm 1.05$ & $0.45 \pm 0.49$ \\
echinocystic acid & $0.29 \pm 0.32$ & $0.59 \pm 0.89$ \\
corosolic acid & $0.04 \pm 0.08$ & $0.00 \pm 0.00$ \\
\hline Glycerol derivatives & $0.60 \pm 0.24$ & $2.23 \pm 0.63$ \\
2-monopalmitin & $0.00 \pm 0.00$ & $0.01 \pm 0.03$ \\
1-monopalmitin & $0.28 \pm 0.14$ & $1.23 \pm 0.52$ \\
1-monoolein & $0.12 \pm 0.14$ & $0.07 \pm 0.10$ \\
1-monostearin & $0.14 \pm 0.05$ & $0.42 \pm 0.31$ \\
docosyl glycerol & $0.02 \pm 0.04$ & $0.16 \pm 0.10$ \\
tetracosyl glycerol & $0.04 \pm 0.05$ & $0.34 \pm 0.18$ \\
\hline Aromatics/Phenolics & $0.56 \pm 0.39$ & $1.13 \pm 0.70$ \\
3-hydroxybenzoic acid & $0.04 \pm 0.09$ & $0.14 \pm 0.13$ \\
vanillic acid & $0.00 \pm 0.00$ & $0.02 \pm 0.05$ \\
caffeic acid & $0.42 \pm 0.27$ & $0.74 \pm 0.64$ \\
docosyl ferulate & $0.06 \pm 0.10$ & $0.13 \pm 0.11$ \\
tetracosyl ferulate & $0.04 \pm 0.07$ & $0.10 \pm 0.10$ \\
\hline Identified & $93.65 \pm 5.63$ & $97.91 \pm 1.01$ \\
Non-identified & $6.35 \pm 5.63$ & $2.09 \pm 1.01$ \\
\hline Total & 100 & 100 \\
\hline
\end{tabular}

\subsection{Suberin Composition}

The results for the suberin composition of $Q$. rotundifolia bark obtained by GC-MS analysis are summarized in Table 6 . The main suberin monomers were fatty acids, representing $85.2 \%$ and $83.7 \%$ of all compounds, from the samples collected at site 1 and site 2 , respectively. Among them, $\omega$-hydroxyacids and $\alpha, \omega$-diacids were the major compounds, representing, on average, $48 \%$ and $20 \%$, respectively. The most abundant compounds were 9,10,18-trihydroxyoctadecanoic acid, 18-hydroxy-9-octadecenoic acid, 22-hydroxydocosanoic acid, and 9,10-dihydroxyoctanedioic acid, with 9.1\%-15.7\%, $13.4 \%-13.7 \%, 9.4 \%-10.1 \%$, and $5.4 \%-7.5 \%$ of all compounds, respectively. Alkanoic acids (saturated and substituted) constituted $14.0 \%$ to $19.1 \%$ of all compounds, aromatics represented between $6.7 \%$ and $9.0 \%$, and alkanols were around $4.4 \%$. Trace amounts of dehydroabietic acid and $\beta$-sitosterol were also identified. In all suberin extracts, compound identification reached between $94.7 \%$ to $98.8 \%$ of all compounds.

Table 6. Suberin composition from Quercus rotundifolia bark sampled at b.h. from trees grown at two sites, in \% of the normalized peak areas in TIC (mean of five trees and standard deviation).

\begin{tabular}{ccc}
\hline Compounds & Site 1 & Site 2 \\
\hline Alkanols & $4.60 \pm 0.79$ & $4.25 \pm 1.02$ \\
octadecanol & $0.16 \pm 0.06$ & $0.20 \pm 0.16$ \\
docosanol & $1.13 \pm 0.14$ & $1.45 \pm 0.35$ \\
tetracosanol & $3.05 \pm 0.61$ & $2.35 \pm 0.72$ \\
hexacosanol & $0.04 \pm 0.01$ & $0.02 \pm 0.03$ \\
3-(2-methoxyethyl)-1-octanol & $0.02 \pm 0.01$ & $0.00 \pm 0.00$ \\
18-methylnonadecanol & $0.08 \pm 0.01$ & $0.12 \pm 0.06$ \\
falcarinol & $0.12 \pm 0.06$ & $0.11 \pm 0.05$ \\
Saturated alkanoic acids & $15.26 \pm 1.30$ & $11.40 \pm 0.84$ \\
\hline
\end{tabular}


Table 6. Cont.

\begin{tabular}{|c|c|c|}
\hline Compounds & Site 1 & Site 2 \\
\hline octanoic acid & $0.07 \pm 0.01$ & $0.04 \pm 0.01$ \\
\hline tetradecanoic acid & $0.03 \pm 0.01$ & $0.01 \pm 0.02$ \\
\hline hexadecanoic acid, methyl ester & $0.49 \pm 0.17$ & $0.38 \pm 0.17$ \\
\hline hexadecanoic acid & $0.42 \pm 0.16$ & $0.38 \pm 0.19$ \\
\hline octadecanoic acid & $0.04 \pm 0.01$ & $0.04 \pm 0.02$ \\
\hline octadecanoic acid, methyl ester & $0.08 \pm 0.02$ & $0.05 \pm 0.03$ \\
\hline eicosanoic acid, methyl ester & $0.13 \pm 0.12$ & $0.08 \pm 0.04$ \\
\hline docosanoic acid, methyl ester & $2.39 \pm 1.02$ & $1.63 \pm 0.53$ \\
\hline tetradecanoic acid, methyl ester & $0.30 \pm 0.09$ & $0.20 \pm 0.06$ \\
\hline tetradecanoic acid & $1.04 \pm 0.22$ & $0.83 \pm 0.14$ \\
\hline docosanoic acid & $1.52 \pm 0.20$ & $0.39 \pm 0.24$ \\
\hline tetracosanoic acid, methyl ester & $7.36 \pm 1.70$ & $6.42 \pm 0.67$ \\
\hline tetracosanoic acid & $0.51 \pm 0.48$ & $0.59 \pm 0.34$ \\
\hline eicosanoic acid & $0.69 \pm 0.46$ & $0.34 \pm 0.33$ \\
\hline hexacosanoic acid & $0.20 \pm 0.38$ & $0.01 \pm 0.03$ \\
\hline Substituted alkanoic acids & $3.80 \pm 1.12$ & $2.38 \pm 1.39$ \\
\hline 9,12-octadecadienoic acid, methyl ester & $0.06 \pm 0.01$ & $0.06 \pm 0.02$ \\
\hline 9-octadecenoic acid (Z)-, methyl ester & $0.28 \pm 0.04$ & $0.20 \pm 0.08$ \\
\hline cis-9-octadecenoic acid & $0.08 \pm 0.03$ & $0.08 \pm 0.03$ \\
\hline 9,12-octadecadienoic acid & $1.69 \pm 1.35$ & $1.52 \pm 1.68$ \\
\hline 9,10-epoxyoctadecanoic acid, methyl ester & $1.23 \pm 0.63$ & $0.25 \pm 0.25$ \\
\hline 9-decenoic acid & $0.45 \pm 0.07$ & $0.26 \pm 0.17$ \\
\hline Saturated $\alpha, \omega$-diacids & $10.83 \pm 3.24$ & $8.02 \pm 2.33$ \\
\hline octanedioic acid & $0.05 \pm 0.00$ & $0.05 \pm 0.02$ \\
\hline hexadecanedioic acid, dimethyl ester & $4.97 \pm 1.51$ & $4.00 \pm 1.36$ \\
\hline eicosandioic acid, dimethyl ester & $1.79 \pm 2.90$ & $0.45 \pm 0.15$ \\
\hline octanedioic acid, dimethyl ester & $3.71 \pm 0.65$ & $3.27 \pm 1.00$ \\
\hline hexadecanedioic acid & $0.08 \pm 0.03$ & $0.06 \pm 0.04$ \\
\hline dodecanedioic acid & $0.11 \pm 0.10$ & $0.00 \pm 0.00$ \\
\hline docosanedioic acid, dimethyl ester & $0.04 \pm 0.04$ & $0.13 \pm 0.18$ \\
\hline heptanedioic acid, methyl ester & $0.01 \pm 0.01$ & $0.00 \pm 0.00$ \\
\hline octanedioic acid, methyl ester & $0.06 \pm 0.05$ & $0.05 \pm 0.05$ \\
\hline Substituted $\alpha, \omega$-diacids & $8.51 \pm 2.66$ & $11.31 \pm 2.79$ \\
\hline 18-methoxyoctanedioic acid & $0.84 \pm 0.71$ & $0.86 \pm 0.58$ \\
\hline 9,10-dihydroxyoctanedioic acid, dimethyl ester & $5.44 \pm 1.07$ & $7.63 \pm 1.22$ \\
\hline 8,9,18-trihydroxyoctanedioic acid, methyl ester & $0.99 \pm 0.96$ & $1.86 \pm 1.65$ \\
\hline 16-hydroxyhexanedioic acid, methyl ester & $1.23 \pm 0.89$ & $0.95 \pm 0.69$ \\
\hline Saturated $\omega$-hydroxyacids & $19.34 \pm 0.95$ & $18.81 \pm 8.44$ \\
\hline 16-hydroxyhexadecanoic acid, methyl ester & $3.08 \pm 1.11$ & $2.65 \pm 0.61$ \\
\hline 16-hydroxydecanoic acid & $0.12 \pm 0.11$ & $0.12 \pm 0.10$ \\
\hline 20-hydroxyeicosanoic acid, methyl ester & $1.08 \pm 0.61$ & $0.79 \pm 0.29$ \\
\hline 20-hydroxyeicosanoic acid & $0.03 \pm 0.03$ & $1.95 \pm 4.36$ \\
\hline 22-hydroxydocosanoic acid, methyl ester & $8.96 \pm 1.22$ & $8.72 \pm 5.00$ \\
\hline 22-hydroxydocosanoic acid & $0.46 \pm 0.51$ & $0.57 \pm 0.48$ \\
\hline 24-hydroxytetracosanoic acid, methyl ester & $5.28 \pm 1.63$ & $3.75 \pm 2.27$ \\
\hline 24-hydroxytetracosanoic acid & $0.32 \pm 0.30$ & $0.26 \pm 0.24$ \\
\hline Substituted $\omega$-hydroxyacids & $27.46 \pm 4.05$ & $30.55 \pm 7.86$ \\
\hline 18-hydroxy-9-octadecenoic acid, methyl ester & $13.70 \pm 1.72$ & $13.76 \pm 1.42$ \\
\hline 9,10-epoxy-18-hydroxyoctadecanoic acid & $0.05 \pm 0.07$ & $0.07 \pm 0.07$ \\
\hline 9,10,18-trihydroxyoctadecanoic acid, methyl ester & $9.14 \pm 0.70$ & $14.93 \pm 6.63$ \\
\hline 9,10-epoxy-18-hydroxyoctadecanoic acid, methyl ester & $4.57 \pm 3.11$ & $1.79 \pm 1.07$ \\
\hline Sterols & $0.01 \pm 0.02$ & $0.03 \pm 0.04$ \\
\hline$\beta$-sitosterol & $0.01 \pm 0.02$ & $0.03 \pm 0.04$ \\
\hline
\end{tabular}


Table 6. Cont.

\begin{tabular}{ccc}
\hline Compounds & Site 1 & Site 2 \\
\hline Terpenes/Terpenoids & $0.02 \pm 0.02$ & $0.03 \pm 0.03$ \\
dehydroabietic acid & $0.02 \pm 0.02$ & $0.03 \pm 0.03$ \\
\hline Aromatics/Phenolics & $8.96 \pm 1.50$ & $6.98 \pm 1.33$ \\
4-methoxybutanoic acid & $0.04 \pm 0.02$ & $0.01 \pm 0.02$ \\
4-hydroxy-benzoic acid, methyl ester & $0.03 \pm 0.02$ & $0.03 \pm 0.03$ \\
3,5-bis(1,1-dimethylethyl)-4-hydroxy-benzoic acid, & $0.32 \pm 0.16$ & $0.13 \pm 0.06$ \\
ethyl ester & $0.05 \pm 0.01$ & $0.02 \pm 0.03$ \\
2,5-dihydroxypyrazine & $0.25 \pm 0.43$ & $0.04 \pm 0.05$ \\
3,4-dihydroxybenzoic acid, methyl ester & $0.07 \pm 0.01$ & $0.07 \pm 0.03$ \\
vanillic Acid & $0.27 \pm 0.09$ & $0.29 \pm 0.35$ \\
isovanillic acid & $0.07 \pm 0.03$ & $0.04 \pm 0.05$ \\
coniferyl aldehyde & $0.02 \pm 0.01$ & $0.03 \pm 0.02$ \\
2,5-dimethoxymandelic acid & $0.06 \pm 0.02$ & $0.07 \pm 0.05$ \\
ferulic acid, methyl ester & $4.25 \pm 1.40$ & $4.64 \pm 0.94$ \\
ferulic acid & $3.53 \pm 0.64$ & $1.60 \pm 0.67$ \\
\hline Identified & $98.79 \pm 0.51$ & $93.77 \pm 3.59$ \\
Non-identified & $1.21 \pm 0.51$ & $6.23 \pm 3.59$ \\
\hline Total & 100 & 100 \\
\hline
\end{tabular}

\section{Discussion}

\subsection{Structure and Anatomy}

The finely square fissured external appearance of the bark of Q. rotundifolia (Figure 1) is in accordance with the available description [36]. The bark is quite different from that of other oaks, and its grey to dark color is also a distinctive characteristic. Bark thickness is highly variable within the species, namely in relation to tree age; a similar bark thickness $(2-6 \mathrm{~mm})$ was reported at $1.5-1.8 \mathrm{~m}$ of stem height for $50-100$ years old trees [32]. The holm oak bark thickness and the rhytidome were narrower compared to Q. petraea (10.5-29.1 mm and 3.7-23.3 mm, respectively) [37] and similar to Q. faginea (5 $\mathrm{mm}$ to $14 \mathrm{~mm}$ ) [28]. The anatomical features of the secondary phloem of the bark of $Q$. rotundifolia (Figures 3A-E, 4A-C, 5A-C and 6A-C) were similar to those of other Quercus species: Q. robur [38,39], Q. sessiliflora [40], Q. petraea [37,41], Q. faginea [28], Q. cerris [29], Q. infectoria, Q. alnifolia, and Q. rubra [36], and other ten Quercus species [42]. The main similarities were in the type of rays (uni/multiseriate), the strong sclerification of cells in the broad multiseriate rays, the occurrence and formation of large groups or clusters of sclereids, and the location of crystals (prismatic crystals and druses). The pattern of rhytidome development with thin sequential periderms in Q. rotundifolia (Figure 2A) was similar to that in various other Quercus species, leading to a low proportion of phellem in these barks (Figure 2A,B,D) and corroborating early findings from holm oak growing in Portugal [30]. Among oaks, one exception is the cork-rich bark of $Q$. cerris, which may have a substantial proportion of phellem in the rhytidome [29], and Q. suber [13] and Q. variabilis [15,43], with only one periderm with a continuous and thick cork layer.

\subsection{Chemical Composition}

The high extractives content and their substantial polar fraction were in line with the anatomical observations of phenolic deposits in the secondary phloem and rhytidome cells (Figures 1B-D and 3A-C). This result aligns with results found in barks of other Quercus spp., such as Q. faginea (total extractives $13.2 \%$, with an $85.6 \%$ proportion of ethanol and water extractives) [23], Q. rubra (12.1\%, with $9.4 \%$ of ethanol-water extract) and Q. robur (23.0\%, with $21.9 \%$ of ethanol-water extract) [26], Q. laurina (14.2\% hot water and $13.6 \%$ ethanol extractives), Q. crassifolia (20.7\% hot water and $11.0 \%$ ethanol extractives), and Q. scytophylla (6.8\% hot water and 4.4\% ethanol extractives) [44], or Q. laurina (19.3\% 
total extractives) and Q. crassifolia (12.7\% total extractives) [25]. The polar extractives content was particularly high at site 2 and the significant differences between sites might be related with the effect of growth season sampling time and/or drought on the formation of these secondary metabolites. In a recent study, Leite et al. [16] analyzed the effect of drought on cork chemical composition and showed that drought enhanced the amount of the polar extractives soluble in ethanol.

The $Q$. rotundifolia bark was low in suberin (about 3\%), a value that fit well with the small amount of phellem tissue in the periderms of in the rhytidome (Figure 2A,B,D). Suberin is the chemical fingerprint of phellem (cork) cells and is not present in other cell types. Therefore, the suberin content is low in barks with little cork development, as shown in other Quercus spp., e.g., Q. faginea (3.9\%) [23], Q. rubra (3.7\%), and Q. robur (3.9\%) [26]. Barks with a substantial proportion of cork have a high content of suberin, e.g., Q. laurina (26.6\%, in outer bark) and Q. crassifolia $(20.1 \%$, in outer bark) [25]. For the cork tissue, the suberin content is higher, e.g., Q. suber (44.8\%) [13], Q. variabilis (39.2\%) [15], Q. cerris $(28.5 \%)$ [45].

The lignin was relatively high $(29 \%$, Table 2$)$, which was in agreement with the thick-walled lignified fibers, sclereids, and fiber-sclereids observed and described above. The bark lignin content was similar to that of $Q$. faginea bark (28.2\%) [23], Q. rubra bark (32.8\%) and Q. robur bark (29.1\%) [26], Q. laurina outer bark (36.9\%), and Q. crassifolia outer bark (39.6\%) [25]. The carbohydrate composition (Table 3) showed a predominance of cellulose and of xylan-based hemicelluloses of the arabino-xylose type, with significant contents of galacturonic acid, rhamnose, and acetyl groups (the sum of xylose, arabinose, galacturonic acid, rhamnose, and acetyl represented $43 \%$ of the monomers). The polysaccharide monomeric composition was similar to that reported for barks of $Q$. faginea [23] and Q. cerris [45], as well as for other species from different taxon, such as Betula pendula [46].

The ash content was very high (Table 2), which is in accordance with the abundant crystals observed mostly in sclereids and in axial parenchyma adjacent to fiber and sieve tube elements.

\subsection{Polar Extract Composition}

The bark of $Q$. rotundifolia was very rich in phenolic compounds that may be solubilized by polar solvents. When considering the extraction of polar compounds successively with ethanol and water, the results showed that most of the phenolics were extracted by ethanol (Table 4), mostly constituted by flavonoids (247.4 mg CE/g extract) and condensed tannins (294.1 mg Ceq/g extract). The subsequent water extraction solubilized the remaining phenolic compounds with much lower proportions of flavonoids (162.5 mg Ceq/g extract) and condensed tannins (41.2 mg Ceq/g extract). Similar reports on high TPC have been given in the literature for Quercus spp. bark polar extracts, even if the extraction procedures differed. For ethanol:water extracts (50:50), Ferreira et al. [23] reported for Q. faginea bark $630.3 \mathrm{mg} \mathrm{GAE} / \mathrm{g}$ of extract of total phenols, $207.7 \mathrm{mg} \mathrm{CE} / \mathrm{g}$ of extract of flavonoids and $220.7 \mathrm{mg} \mathrm{CE} / \mathrm{g}$ of extract of condensed tannins, and Sillero et al. [26] for Q. rubra and Q. robur 276.5-610.6 mg GAE/g of extract of total phenolics and 650.4-1021.8 mg CE/g of extract of flavonoids. Valencia-Avilés et al. [44] compared the ethanol and hot water extraction for Q. laurina, Q. crassifolia, and Q. scytophylla barks and reported high TPC (from 329 to $756 \mathrm{mg} \mathrm{GAE} / \mathrm{g}$ extract) but lower flavonoids (12.9 to $25.4 \mathrm{mg} \mathrm{QE}$, (quercetin)/g extract) and condensed tannins (12.6 to $53.5 \mathrm{mg} \mathrm{CChE} \mathrm{(cyanidin} \mathrm{chloride} \mathrm{equivalents)/g} \mathrm{extract).}$ For methanol:water extracts of Q. suber cork, Santos et al. [47] reported 200-350 GAE/g of extract of phenolics.

The $Q$. rotundifolia bark extracts showed very good antioxidant properties (Table 4). The $\mathrm{IC}_{50}$ values demonstrated this high antioxidant activity $\left(\mathrm{IC}_{50}=4.4 \mu \mathrm{g}\right.$ ethanol extract $/ \mathrm{mL}$ and $4.7 \mu \mathrm{g}$ water extract $/ \mathrm{mL}$ ) when compared to the antioxidant standard Trolox $\left(\mathrm{IC}_{50}=3.3\right.$ and $3.6 \mu \mathrm{g}$ Trolox $/ \mathrm{mL}$, in ethanol and water, respectively). Sillero et al. [26] and Ferreira et al. [23] reported very similar antioxidant properties of ethanol:water bark extracts of $Q$. rubra and Q. robur (399.62 mg TEAC/g extract and $1521.25 \mathrm{mg}$ TEAC/g ex- 
tract, respectively) and $Q$. faginea (1576.12 $\mathrm{mg}$ TEAC $/ \mathrm{g}$ extract; $\mathrm{IC}_{50}=2.63 \mu \mathrm{g}$ extract $/ \mathrm{mL}$ ). Santos et al. [47] reported for $Q$. suber cork an $\mathrm{IC}_{50}$ value of $2.8 \mu \mathrm{g}$ water extract $/ \mathrm{mL}$, $3.6 \mu \mathrm{g}$ methanol extract $/ \mathrm{mL}$ and $5.8 \mu \mathrm{g}$ methanol-water extract $/ \mathrm{mL}$. The results of the FRAP assay follow a similar trend to the one observed in the results obtained for DPPH. The ethanol extracts showed higher FRAP activity than the water extracts with $4.3 \mathrm{mM}$ Trolox/g of extract and $1.3 \mathrm{mM}$ Trolox/g of extract, respectively. In a sequential extraction, water extracts had lower antioxidant properties than ethanol extracts, but they still had compounds with antioxidant capability that were not solubilized in ethanol. The reducing ability by FRAP of both extracts was similar to the values of $4.44 \mathrm{mM}$ TEAC/g of extract for $Q$. faginea bark ethanol:water (50:50) extracts [23].

\subsection{Lipophilic Extracts Composition}

The compositions of lipophilic extractives of $Q$. rotundofolia bark are shown in Table 5. The main constituents were triterpenes ( $49.9 \%$ of all compounds), namely ursolic, betulinic, and oleanolic acids, as well as betulin, with quantitative differences between the two sites. At site 1, the triterpenic acids were much more relevant than betulin, with ursolic, betulinic, and oleanolic acids constituting 35.2\%, 33.4\%, and $13.3 \%$ of all triterpenes, respectively, whereas betulin was only found in small amounts (3.1\% of all triterpenes). However, the opposite was observed in the $Q$. rotundifolia bark samples collected at site 2 -oleanolic acid was found in smaller amounts (only 9.3\% of all triterpenes) and ursolic acid comprised $18.8 \%$ of all triterpenes identified, whereas betulinic acid and betulin represented $21.9 \%$ and $23.7 \%$ of all triterpenes, respectively. Other Quercus species showed different lipophilic compositions, e.g., $Q$. suber cork also included triterpenes belonging to friedelane, lupine, and steroid families, as well as long alkanoic chains [48], but in different amounts; $Q$. cerris cork also showed high amounts of botulin [49]; and Q. variabilis cork also showed a high triterpenic content, representing around 52.0\% of all compounds [43]. Friedelin was found in a fair quantity in the dichloromethane extracts of $Q$. rotundofolia bark (between $1.8 \%$ and 5.0\%), which was slightly higher than the reported for $Q$. suber cork by Castola et al. ([48,50]) and Sousa et al. [51], while it was the main constituent of Q. cerris cork (representing 6.2\%) [14]. Q. rotundofolia bark lipophilic extracts also included long-chain lipid compounds e.g., saturated alkanoic acids (23.7\%-31.2\% of all compounds), constituting $72.4 \%-74.0 \%$ of all long-chain acids. Substituted alkanoic acids, $\alpha, \omega$-diacids and $\omega$-hydroxyacids also existed but in smaller amounts. Similar results have been reported in the literature for Q. faginea barks, where saturated alkanoic acids also constituted an abundant group of compounds (around 25.0\%), with hexadecanoic acid and docosanoic acid as the most representative elements of this family of compounds [23].

\subsection{Suberin Composition}

The results for the suberin composition obtained by GC-MS analysis are summarized in Table 6. The main suberin monomers of $Q$. rotundifolia bark were fatty acids, representing $84.0 \%$ of all compounds, in the samples collected at both sites. Among them, $\omega$-hydroxyacids were the major compounds, representing $46.8 \%$ and $50.2 \%$ in the samples from site 1 and 2, respectively. The most abundant compounds were 9,10,18trihydroxyoctadecanoic acid at site 2 and 18-hydroxy-9-octadecenoic acid at site 1, representing $31.3 \%$ and $29.3 \%$ of all $\omega$-hydroxyacids, respectively. $\alpha, \omega$-Diacids (saturated and substituted) were also abundant, with hexadecanedioic acid and 9,10-dihydroxyoctanedioic acid as the most representative at rates of $25.7 \%$ and $19.4 \%$ of all $\alpha, \omega$-diacids at site 1 and $28.1 \%$ and $38.7 \% \alpha, \omega$-diacids at site 2 , correspondingly. The literature on suberin composition of other oaks shows that it is species specific, i.e., it varies between Quercus species. For instance, in $Q$. faginea bark, suberin is mainly composed by fatty acids, namely $\omega$-hydroxyacids (between $40 \%-50 \%$ of all compounds) and substituted $\alpha, \omega$-alkanoic diacids [23]. In $Q$. suber, for instance, the main constituents of suberin are substituted $\alpha, \omega$-diacids with mid-chain epoxy or diol substitutions [52]. In $Q$. cerris, however, $\omega$ hydroxyacids represent $90 \%$ of the long chain monomers [45], as well as in Q. variabilis 
where $\omega$-hydroxyacids are also the major compounds identified (around $58.7 \%$ ), followed by $\alpha, \omega$-substituted diacids (19.5\%) [43]. Alkanoic acids, aromatics, and alkanols are also present, in amounts varying from around $4.0 \%-19.0 \%$. Trace amounts of dehydroabietic acid and $\beta$-sitosterol were also identified, which was somewhat common in $Q$. faginea barks, where no sterols or triterpenes were identified, as reported by Ferreira et al. [23].

\section{Conclusions}

The general structure and anatomy of $Q$. rotundifolia bark were described for the first time and proved similar to most Quercus spp. The main pattern of $Q$. rotundifolia bark showed a rhytidome with sequential undulated and anastomosed periderms with a small proportion of cork, while the phloem included broad rays with strong cell sclerification, groups of sclereids with embedded large prismatic crystals, and abundant druses in parenchyma cells. The chemical composition of $Q$. rotundifolia bark was also studied for the first time, including variability of composition of lipophilic and polar extracts, and antioxidant activity, as well as suberin composition. The polar extractive content was high, especially for ethanol extracts in regards to total phenolics, flavonoids, and condensed tannins. The $Q$. rotundifolia bark extracts showed very good antioxidant properties and therefore should be considered as a relevant natural source. Certainly, further studies are needed for the identification of single compounds and to gather information on their structural elucidation and their biological activity. Suberin levels were low, in accordance with the bark anatomical characteristics, mainly composed by fatty acids and substituted $\alpha, \omega$-alkanoic diacids. as in various other Quercus spp., but also confirming the betweenspecies variation. These findings constitute the grounds for the valorization of $Q$. rotundifolia bark, which may be integrated into a biorefinery approach with a first step of polar extracts fractionation, thereby contributing to local communities' economies and to the overall sustainability of this species and the montado ecosystem in the western Mediterranean area.

Author Contributions: Conceptualization, V.S. and H.P.; data curation, V.S., J.P.A.F., T.Q., I.M. and H.P.; formal analysis, V.S. and H.P.; investigation, V.S. and J.P.A.F.; methodology, V.S., J.P.A.F., T.Q., I.M. and H.P.; resources, V.S., T.Q. and I.M.; supervision, H.P.; validation, V.S. and I.M.; visualization, V.S.; writing—original draft, V.S., J.P.A.F., T.Q. and I.M.; writing—review and editing, V.S., T.Q., I.M. and H.P. All authors have read and agreed to the published version of the manuscript.

Funding: This work was supported by the Strategic Project (UIDB/00239/2020) of Centro de Estudos Florestais (CEF), by national funding from Fundação para a Ciência e Tecnologia (FCT). The first author also acknowledges a post-doc scholarship (SFRH/BPD/97970/2013) and a research contract (DL57/2016/CP1382/CT0004).

Acknowledgments: The sampling was performed during the first author's post-doc scholarship (SFRH/BPD/97970/2013) funded by Fundação para a Ciência e a Tecnologia (FCT). We thank the private owner L.S. at Mora, as well as the staff from Herdade do Perímetro Florestal da Contenda for their collaboration. We thank Joaquina Silva and Lídia Silva for their help with the chemical analysis.

Conflicts of Interest: The authors declare no conflict of interest.

\section{References}

1. Capelo, J.; Catry, F. Biologia, ecologia e distribuição da azinheira (Biology, ecology and distribution of holm oak). In Os Montados-Muito para Além das Árvores; Fundação Luso-Americana: Lisbon, Portugal, 2007; Volume 3, pp. $119-129$.

2. Franco, J.A. Quercus, L. . In Flora Ibérica, Platanaceae_Plumbaginaceae; Real Jardín Botánico: Madrid, Spain, 1990; Volume II, pp. 15-36.

3. Corcuera, L.; Camarero, J.; Pelegrín, E. Effects of a Severe Drought on Quercus Ilex Radial Growth and Xylem Anatomy. Trees 2004, 18, 83-92. [CrossRef]

4. Montserrat-Martí, G.; Camarero, J.J.; Palacio, S.; Pérez-Rontomé, C.; Milla, R.; Albuixech, J.; Maestro, M. Summer-Drought Constrains the Phenology and Growth of Two Coexisting Mediterranean Oaks with Contrasting Leaf Habit: Implications for Their Persistence and Reproduction. Trees 2009, 23, 787-799. [CrossRef]

5. Fotelli, M.N.; Radoglou, K.M.; Constantinidou, H.-I.A. Water Stress Responses of Seedlings of Four Mediterranean Oak Species. Tree Physiol. 2000, 20, 1065-1075. [CrossRef] [PubMed]

6. Montagnoli, A.; Dumroese, R.K.; Terzaghi, M.; Onelli, E.; Scippa, G.S.; Chiatante, D. Seasonality of Fine Root Dynamics and Activity of Root and Shoot Vascular Cambium in a Quercus ilex L. Forest (Italy). For. Ecol. Manag. 2019, 431, 26-34. [CrossRef] 
7. Vilagrosa, A.; Chirino, E.; Peguero-Pina, J.J.; Barigah, T.S.; Cochard, H.; Gil-Pelegrín, E. Xylem Cavitation and Embolism in Plants Living in Water-Limited Ecosystems. In Plant Responses to Drought Stress: From Morphological to Molecular Features; Aroca, R., Ed.; Springer: Berlin/Heidelberg, Germany, 2012; pp. 63-109. ISBN 978-3-642-32653-0.

8. Pelegrín, E.; Peguero-Pina, J.J.; Sancho-Knapik, D. Oaks Physiological Ecology. In Exploring the Functional Diversity of Genus Quercus L.; Springer: Berlin/Heidelberg, Germany, 2018.

9. Lousã, M.; Fabião, A. A Azinheira: Quercus ilex Ou Quercus rotundifolia? In Sobreiro e Cortiça/Cork oak and Cork, European Conference on Cork oak and Cork, 5-7 May 1997; Pereira, H., Ed.; Centro de Estudos Florestais: Lisboa, Portugal, 1998 ; pp. $248-251$.

10. López-Hidalgo, C.; Trigueros, M.; Menéndez, M.; Jorrin-Novo, J.V. Phytochemical Composition and Variability in Quercus ilex Acorn Morphotypes as Determined by NIRS and MS-Based Approaches. Food Chem. 2021, 338, 127803. [CrossRef]

11. Carvalho, A. Madeiras Portuguesas—Estrutura Anatómica, Propriedades, Utilizações; Direcção-Geral das Florestas: Lisbon, Portugal, 1997.

12. Pereira, H. Cork: Biology, Production and Uses; Elsevier: Amsterdam, The Netherlands, 2007.

13. Pereira, H. The Rationale behind Cork Properties: A Review of Structure and Chemistry. BioResources 2015, 10, 3. [CrossRef]

14. Şen, A.; Quilhó, T.; Pereira, H. The Cellular Structure of Cork from Quercus cerris Var. cerris Bark in a Materials' Perspective. Ind. Crop. Prod. 2011, 34, 929-936. [CrossRef]

15. Miranda, I.; Gominho, J.; Pereira, H. Cellular Structure and Chemical Composition of Cork from the Chinese Cork Oak (Quercus variabilis). J. Wood Sci. 2013, 59, 1-9. [CrossRef]

16. Leite, C.; Oliveira, V.; Miranda, I.; Pereira, H. Cork Oak and Climate Change: Disentangling Drought Effects on Cork Chemical Composition. Sci. Rep. 2020, 10, 7800. [CrossRef]

17. Morales, D. Oak Trees (Quercus spp.) as a Source of Extracts with Biological Activities: A Narrative Review. Trends Food Sci. Technol. 2021, 109, 116-125. [CrossRef]

18. Larcher, W. Physiological Plant Ecology. Ecophysiology and Stress Physiology of Functional Groups, 4th ed.; Springer: Berlin/Heidelberg, Germany, 2003.

19. Falcão, L.; Araújo, M.E.M. Tannins Characterization in Historic Leathers by Complementary Analytical Techniques ATR-FTIR, UV-Vis and Chemical Tests. J. Cult. Herit. 2013, 14, 499-508. [CrossRef]

20. O'Connell, J.E.; Fox, P.F. Effect of Extracts of Oak (Quercus petraea) Bark, Oak Leaves, Aloe Vera (Curacao aloe), Coconut Shell and Wine on the Colloidal Stability of Milk and Concentrated Milk. Food Chem. 1999, 66, 93-96. [CrossRef]

21. Andrenšek, S.; Simonovska, B.; Vovk, I.; Fyhrquist, P.; Vuorela, H.; Vuorela, P. Antimicrobial and Antioxidative Enrichment of Oak (Quercus robur) Bark by Rotation Planar Extraction Using ExtraChrom ${ }^{\circledR}$. Int. J. Food Microbiol. 2004, 92, 181-187. [CrossRef]

22. Scalbert, A.; Monties, B.; Favre, J.-M. Polyphenols of Quercus robur: Adult Tree and in Vitro Grown Calli and Shoots. Phytochemistry 1988, 27, 3483-3488. [CrossRef]

23. Ferreira, J.P.A.; Miranda, I.; Sousa, V.B.; Pereira, H. Chemical Composition of Barks from Quercus faginea Trees and Characterization of Their Lipophilic and Polar Extracts. PLoS ONE 2018, 13, e0197135. [CrossRef]

24. Vangeel, T.; Neiva, D.M.; Quilhó, T.; Costa, R.A.; Sousa, V.; Sels, B.F.; Pereira, H. Tree Bark Characterization Envisioning an Integrated Use in a Biorefinery. Biomass Convers. Biorefin. 2021. [CrossRef]

25. Ruiz-Aquino, F.; González-Peña, M.M.; Valdez-Hernández, J.I.; Revilla, U.S.; Romero-Manzanares, A. Chemical Characterization and Fuel Properties of Wood and Bark of Two Oaks from Oaxaca, Mexico. Ind. Crop. Prod. 2015, 65, 90-95. [CrossRef]

26. Sillero, L.; Prado, R.; Andrés, M.A.; Labidi, J. Characterisation of Bark of Six Species from Mixed Atlantic Forest. Ind. Crop. Prod. 2019, 137, 276-284. [CrossRef]

27. Pereira, H.; Graça, J.; Rodrigues, J. Wood Chemistry in Relation to Quality. Cheminform 2004, 35. [CrossRef]

28. Quilhó, T.; Sousa, V.; Tavares, F.; Pereira, H. Turkish Journal of Botany Bark Anatomy and Cell Size Variation in Quercus faginea. Turk. J. Bot. 2013, 37. [CrossRef]

29. Sen, A.; Quilhó, T.; Pereira, H. Bark Anatomy of Quercus cerris L. Var. cerris from Turkey. Turk. J. Bot. 2011, 35, 33. [CrossRef]

30. Natividade, J.V. Estudo Histologico Das Peridermes Do Hibrido Quercus ilex X suber; Cout, P., Ed.; Dirercção Geral dos Serviços Florestais: Lisbon, Portugal, 1936; Volume III.

31. Berahou, A.; Auhmani, A.; Fdil, N.; Benharref, A.; Jana, M.; Gadhi, C.A. Antibacterial Activity of Quercus ilex Bark's Extracts. J. Ethnopharmacol. 2007, 112, 426-429. [CrossRef]

32. Minganti, V.; Drava, G. Tree Bark as a Bioindicator of the Presence of Scandium, Yttrium and Lanthanum in Urban Environments. Chemosphere 2018, 193, 847-851. [CrossRef] [PubMed]

33. Angyalossy, V.; Evert, R.; Marcati, C.; Oskolski, A.; Terrazas, T.; Kotina, E.; Lens, F.; Cristina, M.-V.; Angeles, G.; Machado, S.; et al. IAWA List of Microscopic Bark Features. Int. Assoc. Wood Anat. 2016, 37, 517-615. [CrossRef]

34. Miranda, I.; Sousa, V.; Ferreira, J.; Pereira, H. Chemical Characterization and Extractives Composition of Heartwood and Sapwood from Quercus faginea. PLoS ONE 2017, 12, e0179268. [CrossRef]

35. Pereira, H. Chemical Composition and Variability of Cork from Quercus suber L. Wood Sci. Technol. 1988, 22, 211-218. [CrossRef]

36. Crivellaro, A.; Schweingruber, F. Atlas of Wood, Bark and Pith Anatomy of Eastern Mediterranean Trees and Shrubs. With a Special Focus on Cyprus; Springer: Berlin/Heidelberg, Germany, 2013; ISBN 978-3-642-37234-6.

37. Gričar, J.; Jagodic, Š.; Prislan, P. Structure and Subsequent Seasonal Changes in the Bark of Sessile Oak (Quercus petraea). Trees 2015, 29, 747-757. [CrossRef]

38. Whitmore, T.C. Studies in systematic bark morphology. New Phytol. 1963, 62, 161-169. [CrossRef]

39. Trockenbrodt, M. Structure and Identification of Root Bark of Quercus robur L. Trees 1995, 9, 341-347. [CrossRef] 
40. Gricar, J. Xylem and Phloem Formation in Sessile Oak from Slovenia in 2007. Wood Res. 2010, 55, 15-22.

41. Vilkovský, P.; Cunderlík, I. Structure of phloem and wood/bark shear strength of the sessile oak during dormant and growing period. Acta Fac. Xylologiae 2017, 59, 17-26. [CrossRef]

42. Howard, E.T. Bark Structure of Southern Upland Oaks; USDA: Washington, DC, USA, 1977.

43. Ferreira, J.; Miranda, I.; Sen, A.; Pereira, H. Chemical and Cellular Features of Virgin and Reproduction Cork from Quercus variabilis. Ind. Crop. Prod. 2016, 94. [CrossRef]

44. Valencia-Avilés, E.; García-Pérez, M.E.; Garnica-Romo, M.G.; Figueroa-Cárdenas, J.D.; Meléndez-Herrera, E.; Salgado-Garciglia, R.; Martínez-Flores, H.E. Antioxidant Properties of Polyphenolic Extracts from Quercus laurina, Quercus crassifolia, and Quercus scytophylla Bark. Antioxidants 2018, 7, 81. [CrossRef]

45. Şen, A.; Miranda, I.; Santos, S.; Graça, J.; Pereira, H. The Chemical Composition of Cork and Phloem in the Rhytidome of Quercus cerris Bark. Ind. Crop. Prod. 2010, 31, 417-422. [CrossRef]

46. Miranda, I.; Gominho, J.; Mirra, I.; Pereira, H. Fractioning and Chemical Characterization of Barks of Betula pendula and Eucalyptus globulus. Ind. Crop. Prod. 2013, 41, 299-305. [CrossRef]

47. Santos, S.A.O.; Pinto, P.C.R.O.; Silvestre, A.J.D.; Neto, C.P. Chemical Composition and Antioxidant Activity of Phenolic Extracts of Cork from Quercus suber L. Ind. Crop. Prod. 2010, 31, 521-526. [CrossRef]

48. Castola, V.; Marongiu, B.; Bighelli, A.; Floris, C.; La1, A.; Casanova, J. Extractives of Cork (Quercus suber L.): Chemical Composition of Dichloromethane and Supercritical $\mathrm{CO}_{2}$ Extracts. Ind. Crop. Prod. 2005, 21, 65-69. [CrossRef]

49. Sen, A.; Melo, M.; Silvestre, A.; Pereira, H.; Silva, C. Prospective Pathway for a Green and Enhanced Friedelin Production through Supercritical Fluid Extraction of Quercus cerris Cork. J. Supercrit. Fluids 2015, 97, 247-255. [CrossRef]

50. Castola, V.; Bighelli, A.; Rezzi, S.; Melloni, G.; Gladiali, S.; Desjobert, J.-M.; Casanova, J. Composition and Chemical Variability of the Triterpene Fraction of Dichloromethane Extracts of Cork (Quercus suber L.). Ind. Crop. Prod. 2002, 15, 15-22. [CrossRef]

51. Sousa, A.F.; Pinto, P.C.R.O.; Silvestre, A.J.D.; Pascoal Neto, C. Triterpenic and Other Lipophilic Components from Industrial Cork Byproducts. J. Agric. Food Chem. 2006, 54, 6888-6893. [CrossRef]

52. Clermont, L.P. The Fatty Acids of Aspen Poplar, Basswood, Yellow Birch and White Birch. Pulp Paper Mag. Can. 62 1961, 3, T511-T514. 